How to cite: Boicu, D., Minea, I., Chelariu, O.-E., Iosub, M. (2019) Evaluation on Groundwater Recharges Capacity Using the AHP Method - Case Study: The Moldavian Plain. 2019 "Air and Water - Components of the Environment" Conference Proceedings, Cluj-Napoca, Romania, p. 181-188, DOI: 10.24193/AWC2019_18.

\title{
EVALUATION ON GROUNDWATER RECHARGES CAPACITY USING THE AHP METHOD - CASE STUDY: THE MOLDAVIAN PLAIN
}

\author{
Daniel BOICU ${ }^{1}$, Ionuț MINEA ${ }^{1}$ 囚, Oana-Elena CHELARIU ${ }^{1}$, Marina IOSUB $^{1}$ \\ DOI: 10.24193/AWC2019_18
}

\begin{abstract}
In the context in which the distribution of the phreatic level represents one of the main components regarding the water supply of the population, it was necessary to approach a method aimed at highlighting the areas where the underground recharging capacity is favorable or unfavorable. In the present study, this technique called AHP (Analytical Hierarchy Process) was used to highlight the distribution of groundwater recharge areas in the Moldavian Plain area by assigning weight factors to each thematic layer. In the realization of the study were used thematic layers such as drainage density, slope, land use, precipitation distribution, groundwater level, soils, lithology. For the final map, we used the weighted overlay toolbox from the ArcGis software, giving the weight factor for each thematic layer. The new thematic layer was divided into 5 classes to highlight their distribution within the study area.
\end{abstract}

Keywords: groundwater, recharge, AHP, Moldavian Plain, GIS

\section{INTRODUCTION}

Groundwater resources management it has a strategic importance in the social and economic security, due the fact that in some regions the groundwater resources are the main source of population water supply. A number of studies have been conducted globally to assess the vulnerability of groundwater resources in the regions with restrictive climate conditions (Lloyd, 2007; Shamsudduha et al., 2012; Bahir et al., 2013, Apostol et al., 2015, Chen et al., 2016) or with anthropic impact on the quality of groundwater (Cunningham et al., 2006; Minea \& Crăciun, 2012; Li et al., 2016; Zhang et al., 2017).

The northeast part of Romania, Moldova Region, can be included in the region with restrictive climate condition and with a high anthropic impact on the supply and quality of the groundwater. The situation of ground-water supply of the study area is partially known because it is monitored only at the level of the main river

\footnotetext{
1 "Alexandru Ioan Cuza" University of Iași, Romania, Faculty of Geography and Geology, e-mail: ionutminea1979@yahoo.com
} 
beds. Moldova Plain covers an area of more than $8000 \mathrm{~km}^{2}$, about $50 \%$ of its population lives in rural areas, and the main sources of population water supply is given by the groundwater, exploited mainly through individual wells. Amid social and economic changes which the eastern part of Romania is facing, it is necessary to re-evaluate the water consume and the conditions for recharging the groundwater resources, this is important mainly in under-monitored areas where the impact of climate change, cumulated with the anthropic one, brings serious changes in the regime, the quality and the tendency of evolution of the underground waters (Minea et al., 2012). The main aim of this paper is to determine the ground-water capacity of recharge in the northeastern part of Romania in the circumstance of regional climatic variations.

\section{DATA AND METHODS}

\subsection{Study area}

The study area is located in the Botoșani and Iași counties, northeastern part of Romania, and it's represent by geographical unit: Moldavian Plain (Fig. 1). The area of Moldavian Plain occupies a total of about $8000 \mathrm{~km}^{2}$. The hypsometric range value in the area is relatively low, average altitudes varies between 50 and $250 \mathrm{~m}$. The specific climatic conditions are those characteristic of the temperate continental climate type, with average annual precipitations of 520-600 $\mathrm{mm}$ and with average annual temperature of $8-9^{\circ} \mathrm{C}$. Most of the studied area is used for agricultural purposes, the second class of land cover is determined by pasture, natural grass land and deciduous forest.

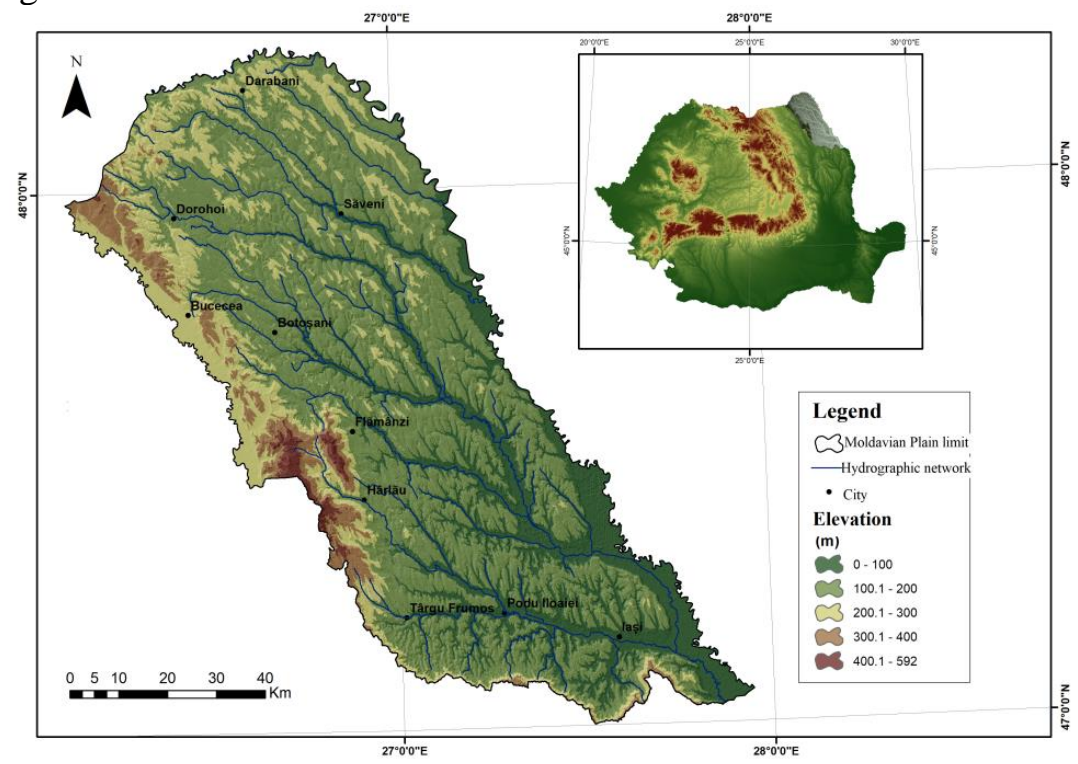

Fig. 1. Geographical location of the study area 


\subsection{Data used}

Within the analysis of the areas with different physical proprieties of rechargeable ground-water supply, for Moldova Plain, 7 physico-geographical factors were taken into account: precipitation, hydrographic network density, soil texture, lithology, slope, land use and the groundwater level. In order to obtain the thematic layers, the following sets of data were used:

- the meteorological data on the multiannual average precipitation from 1961 to 2013 were processed on the basis of the ROCADA data set (Romanian Climatic Dataset), covering Romania (Bîrsan \& Dumirescu, 2014, Dumitrescu \& Bîrsan, 2015);

- the thematic layer used to generate the slope and the hydrographic network density was the Numeric Model of the Terrain ASTER GDEM with a pixel size of 30x30 meters was used. The DEM used was downloaded from USGS site (https://lpdaac.usgs.gov/);

- the land use layer was downloaded of Land Copernicus site, from Corine Land Cover, year 2012, database (https://land.copernicus.eu/);

- in order to obtain the thematic layer on the piezometric distribution, wells were digitized on the topographic maps at the 1:25000 scale. And also, were digitized the hydrostatic level measurements performed at hydrogeological drillings monitored by the Prut-Bârlad Water Administration Branch, managed by National Water Administration;

- lithology and soil texture were generated by digitizing the 1:200000 scale geological and pedagogical maps (Institutul Geologic Român, 1968; Institutul de Cercetări pentru Pedologie și Agrochimie, București, 1990).

\subsection{Methods - AHP Simulation}

This method has a large range of domains where it can be applied (Hapciuc et al., 2016). This type of GIS techniques used to identify the potential of aquifers recharging have been described by Nag and Gosh in 2013.

For each analyzed factor, it was generated a thematic layer, which was later included in the methodological stages of the Analytical Hierarchy Process (AHP). In the figure 2 it can be observed the stages the evaluation algorithm for each factor and the way of inclusion in the AHP algorithm.

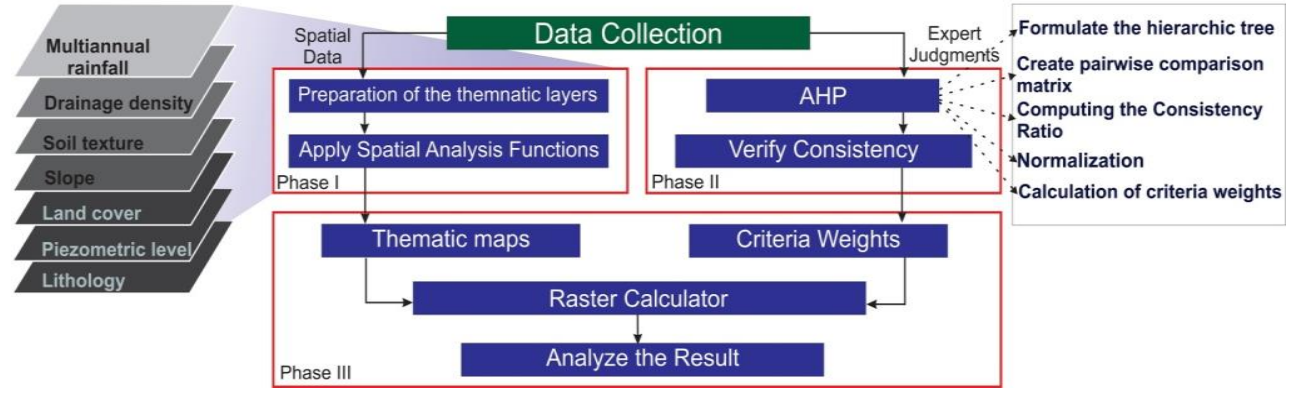

Fig. 2. The methodological structure (source: Hapciuc et al., 2016) 
For AHP analysis, it is necessary to create a matrix based on the pairing of input data. Its purpose is to prioritize data according to its importance in obtaining the final values. According to Saaty's proposed methodology (1980) based on the obtained thematic layers, comparing pairs of alternatives are assigned within a matrical patter, based on the importance grade between two factors, values vary between 1 to 5 , depending on the impact on recharge, where 1 is the minimum impact and 5 the maximum impact (Table 1).

Table 1. Value compare matrix

\begin{tabular}{|l|c|c|c|c|c|c|c|}
\hline & $\begin{array}{c}\text { Piezometric } \\
\text { level }\end{array}$ & $\begin{array}{c}\text { Land } \\
\text { use }\end{array}$ & $\begin{array}{c}\text { Hydrographi } \\
\text { c network }\end{array}$ & Lithology & Slope & $\begin{array}{c}\text { Soil } \\
\text { (texture) }\end{array}$ & Precipitation \\
\hline $\begin{array}{l}\text { Piezometric } \\
\text { level }\end{array}$ & 1 & 0.5 & 0.5 & 0.2 & 0.5 & 0.33 & 0.2 \\
\hline Lan use & 2 & 1 & 0.50 & 0.25 & 0.5 & 0.33 & 0.2 \\
\hline $\begin{array}{l}\text { Hydrographi } \\
\text { c network }\end{array}$ & 2 & 2 & 1 & 0.33 & 0.5 & 0.5 & 0.33 \\
\hline Lithology & 5 & 4 & 3 & 1 & 0.5 & 3 & 0.33 \\
\hline Slope & 2 & 2 & 2 & 2 & 1 & 0.5 & 0.33 \\
\hline Soil(texture) & 3 & 3 & 2 & 0.33 & 2 & 1 & 0.33 \\
\hline Precipitation & 5 & 5 & 3 & 3 & 3 & 3 & 1 \\
\hline
\end{tabular}

The next step, in order to finalize the analysis, was the normalization of values from matrix, identification and calculation of weight factors. To verify and validate the pair comparative judgements it was calculated Consistency Index (C.I.) [Equation 1] and Random Consistency Index (R.I.) after that, Consistency Ratio (C.R.) [Equation 2], depending on the number of factors considered (Forman, 2001).

$$
\begin{aligned}
& \text { C.I }=\frac{\lambda \max -n}{n-1} \\
& \text { C.R. }=\frac{C . I .}{R . I}
\end{aligned}
$$

Consistency Ratio value is 0.066 . This value being below the threshold of 0.10 is considered to be acceptable and the assay matrix validated (Hapciuc et al., 2016). The final map was obtained as a sum of the weight of each factor with the corresponding thematic layer [Equation 3].

$$
\begin{aligned}
& \mathrm{GPR}=(3.2 * \mathrm{P})+(2.00 * \mathrm{~L})+(1.46 * \mathrm{~T})+(1.38 * \mathrm{~S})+(0.84 * \mathrm{DD})+(0.58 * \mathrm{LU})+(0.46 * \mathrm{PL}) \\
& \text { where: } \\
& \quad \begin{array}{l}
\text { GPR-groundwater potential recharge; } \\
\text { P-precipitation; } \\
\text { L-lithology; } \\
\text { T-texture; } \\
\text { S-slope; }
\end{array}
\end{aligned}
$$




\section{DD-drainage density; \\ LU-land use; \\ PL-piezometric level.}

In estimating groundwater recharge, the factor with the greatest weight is given by precipitation -3.2 , followed by lithology -2 , soil texture -1.46 , slope -1.38 , drainage density -0.84 , land use -0.58 and piezometric level -0.46 .

\section{RESULTS AND DISCUSSIONS}

Over $77.4 \%$ of the surface of Moldavian Plain is characterized by a maximum depth of the piezometric level greater than $3.2 \mathrm{~m}$, which reduces the recharge time of the aquifers. Other conditions that are reducing the recharging time of aquifers in the studied area are: piezometric level with values greater than 5 meters and clay or clay-marne layers with a high grade of imperviousness. The depth of piezometric level has been spatialized using the Kriging spatial interpolation (Yue Sun et al, 2009). 82\% of the Moldavian Plain area is characterized by slopes ranging from 1 to 5 degrees $(64 \%)$ or less than 1 degree (18\%). The low slopes cause a slow drainage of water on the versants and it is possible to accumulate in micro-depressions or river meadow. In these areas there is the greatest possibility of groundwater infiltration and aquifers recharging (Chakrabortty et al., 2018).

In order to analyze the aquifer recharge potential in the northeastern part of Romania, 5 classes were identified: very high, high, medium, low and very low (Fig. $3)$. Following the analysis, it is noticed that the groundwater recharge potential is very low in the central-southern part of the Moldavian Plain for $786.2 \mathrm{~km}^{2}$, which means $9.9 \%$ of the studied area. A high potential of groundwater recharge is identified on the western part of the Moldavian Plain, being specific for $4.8 \%$ of the area. According to comparative matrix on pairs the distribution of groundwater potential recharge is determined by to factors: precipitation which has a weight in equation of $33 \%$ and lithology whit a weight of $20 \%$. The factors that influence in a minor manner are land use and piezometric level with a weight in equation on $6 \%$ and $5 \%$. Under this condition it can be considered that the groundwater recharge potential is not greatly influenced by the depth and position of aquifers. The spatial distribution of precipitation remains, as it has been identified in other scientific papers, the main factor in underwater recharge. This fact makes the whole region vulnerable to climate change (Minea \& Croitoru, 2015, 2017).

According to the groundwater recharge potential map obtained, it can be seen that more than $70 \%$, over $5600 \mathrm{~km}^{2}$, of Moldavian Plain's surface is characterized by medium and low classes of groundwater potential recharge. These areas are located in the central-southern part of the plain, this low potential can be explained by the smaller amount of precipitation and by the imperviousness of the clay substrate. The class with a high potential for recharging of aquifers, is specific for 5\% of the analyzed area, and are situated in the western area of the Moldavian Plain, appears due to some significant lithological changes (the clay is replaced by sandy deposits) 
and the amount of precipitation raise significantly (over $550 \mathrm{~mm}$ annual average). $10 \%$ of the Moldova Plain area is characterized by the very low potential for recharging of aquifers, the spatial distribution of this class overlaps the higher areas of the central and northern part of the Plain, with altitudes over $200 \mathrm{~m}$, where the water infiltration from the hydrographic network in aquifers is significantly reduced.

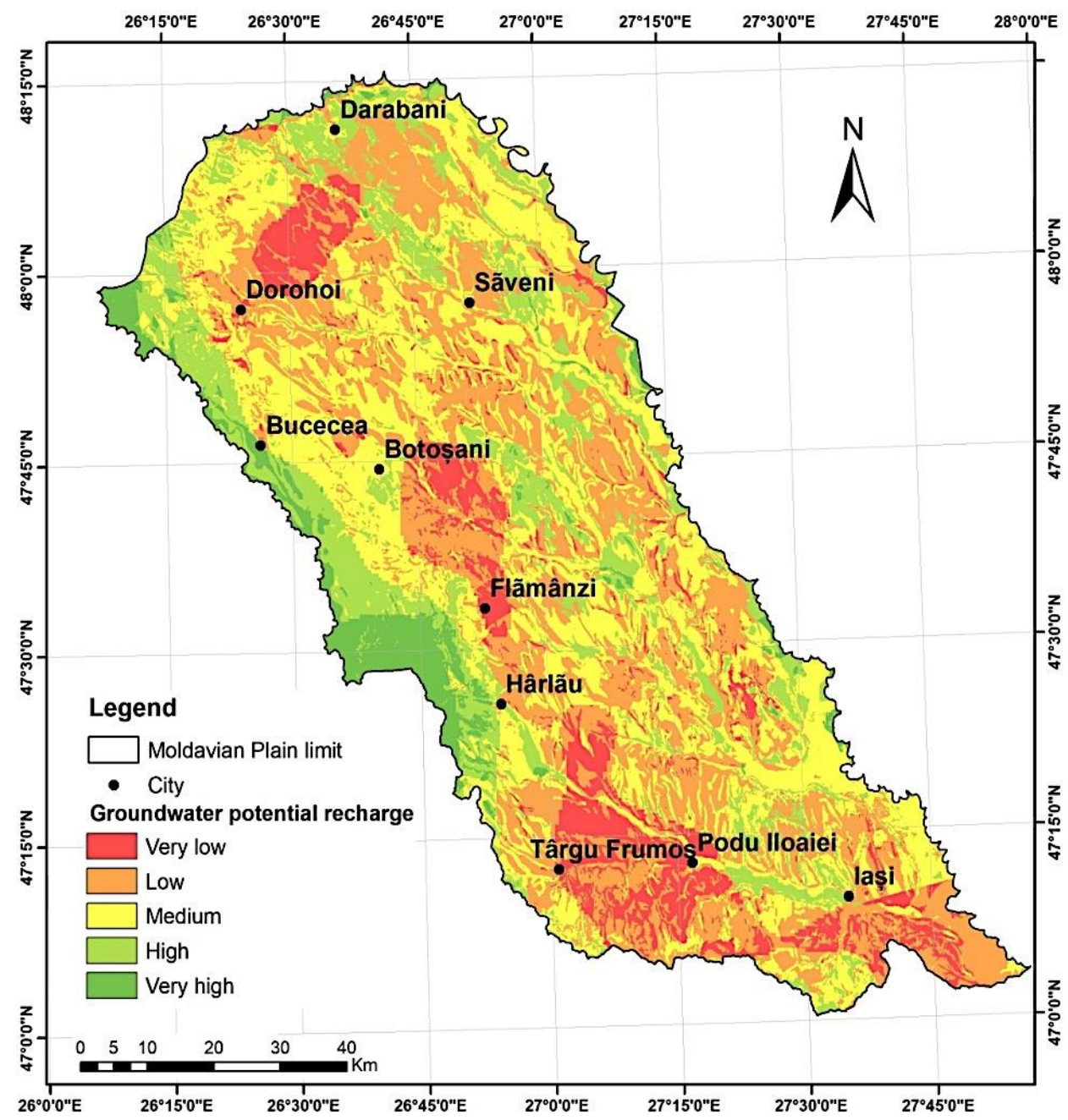

Fig. 3. Groundwater potential recharge

\section{CONCLUSIONS}

The obtained results demonstrate that the integration of GIS technique with the AHP methodology provides an important tool for analyzing the potential of aquifers recharging. This type of methodology may underlie management plans of 
groundwater resources by identifying factors that generate variations and influences their long-term development taking into account the evolution of climatic parameters. If climate changes in the future it will greatly influence the amount of annual precipitation then it is necessary to adjust the groundwater consumption in order to avoid the raise of anthropic factor on the long term.

\section{REFERENCES}

1. Apostol, L., Bărcăcianu, F., Ichim, P., \& Sfîcă, L., (2015). The thermal inversion phenomena on ground level and in the free atmosphere in the first $3000 \mathrm{~m}$ above Moldova, Romania. Advances in Environmental Sciences, 7(2), 196-204.

2. Bahir, M., Chamchati, H., El Moukayar, R., Youbi, N., Chkir, N., (2013). Managment and protection of groundwater resources in semiarid zones: Application of hydrochemical methodologies to Essaouira synclinal basin (Morocco). International Journal of Hydrology Science and Technology, 3, 160-175.

3. Bîrsan M.V, Dumitrescu A., (2014), ROCADA: Romanian daily gridded climatic dataset (1961-2013) V1.0. Administrația Națională de Meteorologie, București, România.

4. Chakrabortty R, Pal S.C Malik S, Das B, (2018). Modeling and mapping of groundwater potentiality zones using AHP and GIS technique: a case study of Raniganj Block, Paschim Bardhaman, West Bengal, Modeling Earth Systems and Environment, 4:1085-1110 doi.org/10.1007/s40808-018-0471-8.

5. Chen J, Wu H, Qian H, Li X., (2016). Challenges and prospects of sustainable groundwater management in an agricultural plain along the Silk Road Economic Belt, north-west China, International Journal of Water Resources Development, 34 (3): 354-368, doi.org/10.1080/07900627.2016.1238348.

6. Cunningham, J. A., \& Mendoza-Sanchez, I. (2006). Equivalence of two models for biodegradation during contaminant transport in groundwater. Water resources research, 42(2) pp. $1-10$.

7. Dumitrescu A, Bîrsan M.V, (2015). ROCADA: a gridded daily climatic dataset over Romania (1961 -2013) for nine meteorological variables, Natural Hazards, 78(2), $1045-1063$.

8. Forman E, Gass S, (2001). The analytic hierarchy process-an. Operations research vol. 49, No. 4, July-August 2001, pp. 469-486.

9. Hapciuc, O.E., Iosub, M., Tomasciuc, A.I., Minea, I., Romanescu, G. (2016). Identification of the potential risk areas regarding the floods occurrence within small mountain catchments. 2nd International Scientific Conference Geobalcanica, $177-183$

10. Li P., (2016). Groundwater quality in Western China: Challenges and paths forward for groundwater quality research in Western China. Expo Health, 8(3): 305-310. doi:10.1007/s12403-016-0210-1

11. Lloyd J.W (2007). The difficulties of regional groundwater resources assessments in arid areas, Arab J Sci Eng. 32:35-47.

12. Minea I., Crăciun I., (2012). Simulation models to evaluate the groundwater resources in Bahlui river basin, Romania. Journal of Enviromental Protection and Ecology, 1600-1607. 
13. Minea I., Butelcă D., Niacşu L., (2012). Modele de variaţie a nivelului freatic în condiţii de secetă. Studiu de caz bazinul superior al Bârladului, Geographia Napocensis, IV, 1, 75-82 (in Romanian)

14. Minea I, Croitoru A.E (2015). Climate Changes and their impact on the variation of groundwater level in the Moldavian Plateau (Eastern Romania), SGEM 2015, Conference Proceedings, Vol. I, 137-145, DOI: 10.5593/sgem2014B31;

15. Minea I, Croitoru A.E., (2017). Groundwater response to changes in precipitations in north-eastern Romania, Environmental Engineering and Management Journal, $16,3,643-651$.

16. Nag SK, Ghosh P. (2013), Delineation of groundwater potential zone in Chhatna Block, Bankura District, West Bengal, India using remote sensing and GIS techniques. Environ Earth Sci 70(5):2115-2127.

17. Saaty T.L. (1980), The Analytic Hierarcy Process, McGraw-Hill: New York, NY, USA

18. Shamsudduha M., Taylor R.G., Longuevergne L (2012). Monitoring groundwater storage changes in the highly seasonal humid tropics: Validation of GRACE measurements in the Bengal Basin, Water Resources Research, Vol. 48, Issue 2, DOI: 10.1029/2011WR010993.

19. Yue S, Shaozhong K, Fusheng Li, Lu Zhang, (2009). Comparison of interpolation methods for depth to groundwater and its temporal and spatial variations in the Minqin oasis of northwest China. Environmental Modelling \& Software. https://doi.org/10.1016/j.envsoft.2009.03.009

20. Zhang H.W, Sun Y.Q, Li Y, Zhou X.D, Tang X.Z, Yi P, Murad A, Hussein S, Alshamsi D, Aldahan A, Yu Z.B, Chen X.G, Mugwaneza V.D.P (2017). Quality assessment of groundwater from the south-eastern Arabian Peninsula, Environ Monit Assess. 189(8):411. doi: 10.1007/s10661-017-6092-2.

21.*** (1968), Harta geologică a României, scara 1: 200 000, Institutul Geologic Român.

22. *** (1990), Harta solurilor României, scara 1: 200 000, Institutul de Cercetări pentru Pedologie și Agrochimie, București.

23. *** http://land.copernicus.eu/pan-european Accessed on 15.10.2018.

24. *** https://gdex.cr.usgs.gov/gdex/ Accessed on 15.10.2018. 